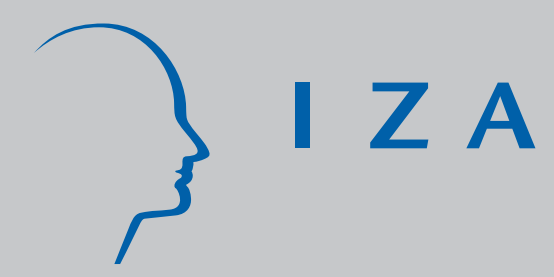

IZA DP No. 3066

Capital Accumulation and Unemployment: New Insights on the Nordic Experience

Marika Karanassou

Hector Sala

Pablo F. Salvador

September 2007 


\title{
Capital Accumulation and Unemployment: New Insights on the Nordic Experience
}

\author{
Marika Karanassou \\ Queen Mary, University of London \\ and IZA \\ Hector Sala \\ Universitat Autònoma de Barcelona \\ and IZA \\ Pablo F. Salvador \\ Universitat Autònoma de Barcelona \\ and Universitat Pompeu Fabra
}

Discussion Paper No. 3066

September 2007

\author{
IZA \\ P.O. Box 7240 \\ 53072 Bonn \\ Germany \\ Phone: $+49-228-3894-0$ \\ Fax: +49-228-3894-180 \\ E-mail: iza@iza.org
}

\begin{abstract}
Any opinions expressed here are those of the author(s) and not those of the institute. Research disseminated by IZA may include views on policy, but the institute itself takes no institutional policy positions.
\end{abstract}

The Institute for the Study of Labor (IZA) in Bonn is a local and virtual international research center and a place of communication between science, politics and business. IZA is an independent nonprofit company supported by Deutsche Post World Net. The center is associated with the University of Bonn and offers a stimulating research environment through its research networks, research support, and visitors and doctoral programs. IZA engages in (i) original and internationally competitive research in all fields of labor economics, (ii) development of policy concepts, and (iii) dissemination of research results and concepts to the interested public.

IZA Discussion Papers often represent preliminary work and are circulated to encourage discussion. Citation of such a paper should account for its provisional character. A revised version may be available directly from the author. 
IZA Discussion Paper No. 3066

September 2007

\section{ABSTRACT \\ Capital Accumulation and Unemployment: New Insights on the Nordic Experience ${ }^{*}$}

This paper takes a fresh look at the analysis of labour market dynamics and argues that capital accumulation plays a fundamental role in shaping unemployment movements. This role has generally been examined by considering indirect transmission channels of the capital stock effects, i.e. using variables like interest rates or investment ratios in the estimation of single-equation unemployment rate models. Here we advocate a different approach. We directly estimate the effects of capital stock in the labour market by applying the chain reaction theory of unemployment, and we find that capital stock is a major determinant of unemployment in the Nordic countries. In particular, the different unemployment experiences of these economies derive from the temporary (albeit prolonged) negative shocks to capital stock growth in Denmark and Sweden, and the permanent downturn of capital stock growth in Finland. We are thus able to explain why the crisis of the early 1990s had a more acute impact in Finland than in its twin economy, Sweden.

JEL Classification: E22, E24, J21

Keywords: unemployment dynamics, chain reaction theory, capital accumulation, Nordic countries

Corresponding author:

Hector Sala

Departament d'Economia Aplicada

Universitat Autònoma de Barcelona

08193 Bellaterra

Spain

E-mail: hector.sala@uab.es

\footnotetext{
* We are grateful to Jaakko Pehkonen for his valuable comments on earlier versions of this paper. Hector Sala is grateful to the Spanish Ministry of Education and Science for financial support through grant SEJ2006-14849/ECON.
} 


\section{Introduction}

The interest in the capital-unemployment relationship has been revived over the recent years. ${ }^{1}$ In this paper we examine the proposition that the slowdown in the growth rate of capital is responsible for the rise in the unemployment rate. We argue that capital stock is a determinant of unemployment, both in the short- and the long-run, and show that capital accumulation can explain the diverse unemployment experiences of the Nordic countries.

These economies are normally grouped together due to their well developed welfare state system, low levels of income inequality and successful performance vis-à-vis continental Europe. Nevertheless, the unemployment trajectories of the three countries in Figure 1 display significant disparities which are usually overlooked. While Sweden and Finland came out of the oil crises with hardly any damage, Denmark witnessed a substantial increase in its unemployment over the late 1970s and early 1980s. In contrast, although the 1990s crisis first hit Denmark, it did so less intensively than in Sweden and Finland. We should also note the remarkable similarity in shape, and disparity in magnitude, of the unemployment paths in these two economies.

The contribution of our work is a country-specific analysis of the Nordic economies where the evolution of capital accumulation accounts for the above heterogeneities. A bird's-eye view of the capital-unemployment relationship in the three countries is depicted in Figure 2: the correlation between the rates of unemployment and capital stock growth is -0.67 in Denmark, -0.52 in Sweden, and -0.91 in Finland.

Figure 1. Unemployment rate
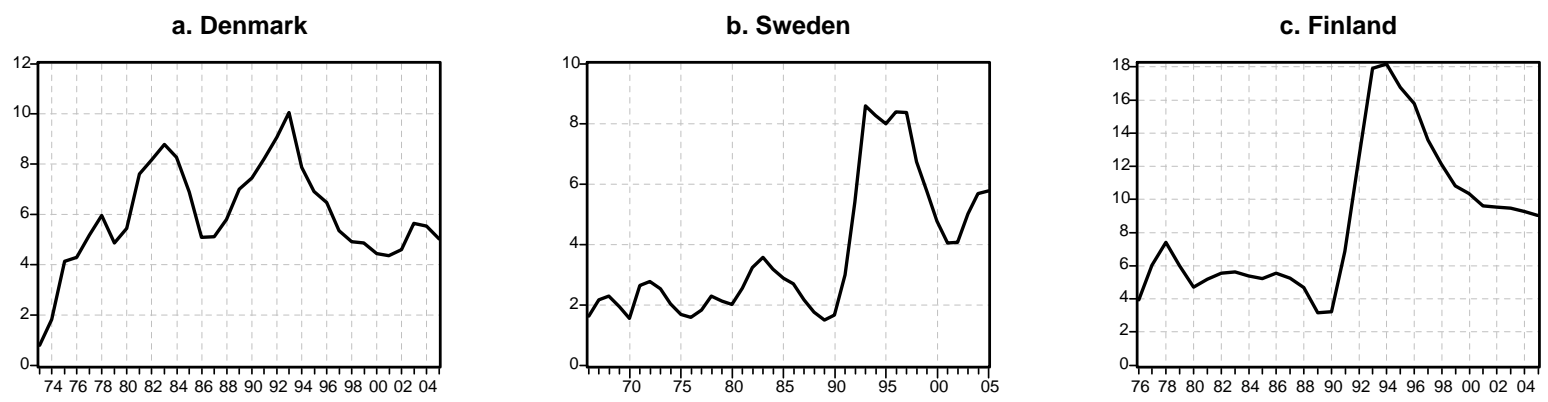

There is a tendency in the literature to examine the influence of capital stock on unemployment by using single unemployment rate equations and proxy variables such as real interest rates, real balances or investment ratios. There are reasonable doubts

\footnotetext{
${ }^{1}$ See, among others, Rowthorn (1999), Malley and Moutos (2001), Karanassou and Snower (2004), and Arestis, Baddeley and Sawyer (2007). A summary documentation of this macro-labour literature is given in Section 2.
} 
as to whether these proxies can capture the effects of capital accumulation net of other influences. ${ }^{2}$ Quite often the influence of capital stock is hidden behind non-controversial accounts of the unemployment upturns due to rises in interest rates or financial crises. Furthermore, single-equation unemployment rate models cannot take full account of the transmission channels of the unemployment effects of capital stock (e.g. its effect on labour demand).

Figure 2. Correlation of unemployment and capital accumulation

a. Denmark

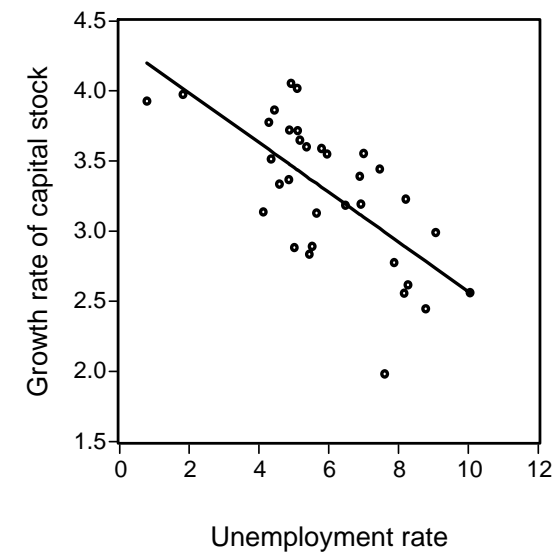

b. Sweden

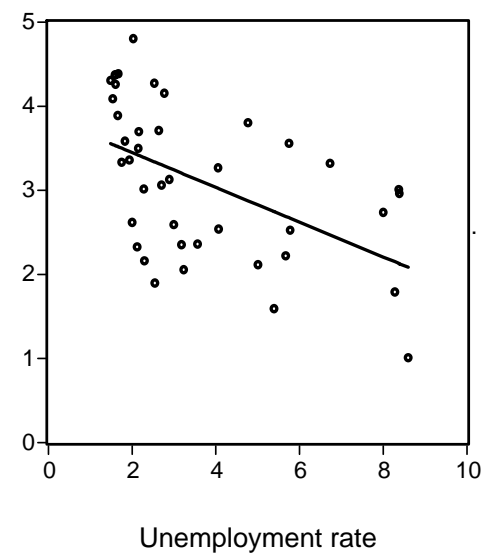

c. Finland

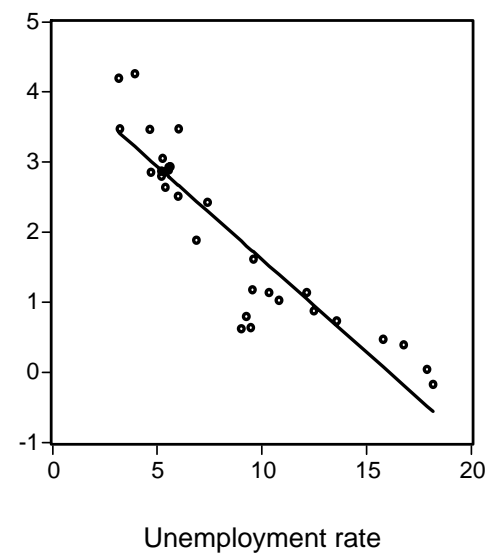

To explain the unemployment hikes of the 1970s and early 1980s in Denmark, GreenPedersen (2001) and Green-Pedersen and Lindbom (2005) point to interest rates as one of the main driving forces under the deteriorated international wage competitiveness and the decrease in the terms of trade that pushed unemployment upwards.

Honkapohja and Koskela (1999) attribute the unemployment problem in Finland to the financial crisis resulting from the pre-1992 overheating of the economy, the collapse of asset prices and the subsequent high indebtedness of firms and households, which were worsened with an interest rate rise to defend the exchange rate of the Markka. We believe that the main manifestation of the Finnish financial crisis is the permanent drop in its growth rate of capital stock that we identify in Section $5 .^{3}$

Fregert and Pehkonen (2006) provide a comparative review of some of the most influential studies analysing the Finnish and Swedish labour markets in the 1990s. Based

\footnotetext{
${ }^{2}$ For example, it is certainly true that a fall in interest rates (or a rise in real balances) may cause higher investment and, thereby, larger capital availability and new hirings, but it may also be capturing positive employment effects on account of the enhanced private consumption brought by this fall (rise). In this case it would be appropriate to include consumption as an explanatory variable in the estimation.

${ }^{3}$ The fact that Denmark did not suffer a similar banking crisis is attributed by Edey and Hviding (1995) to a more prudential supervision of Danish banks and tighter capital standards.
} 
on the combined evidence of the surveyed works and their own estimates they conclude that the main driving forces of the Finnish unemployment were the rise in interest rates, productivity shocks and tax changes. Productivity shocks and tax changes were also significant in Sweden, but with a smaller impact, while interest rates seem to have played no role. ${ }^{4}$

This paper measures the unemployment effects of capital accumulation by applying the Chain Reaction Theory (CRT) of unemployment and estimating a dynamic multi-equation labour market model with spillover effects (i.e. an interactive dynamics model)..$^{5}$

Since the unemployment rate is a nontrended variable, single-equation unemployment models have to use exogenous variables that do not display a trend. This is not the case with multi-equation labour market models - the only requirement is that each trended endogenous variable (e.g. employment, real wage, labour force) is balanced with the set of its explanatory variables. Thus the CRT allows us to evaluate the role of capital stock on the evolution of unemployment via its influence on labour demand.

The CRT views macroeconomic activity as the result of the interplay between lagged adjustment processes and changes in the exogenous variables feeding through the labour market system. ${ }^{6}$ The lagged adjustment processes are well documented in the literature and refer, among others, to: (i) employment adjustments arising from labour turnover costs (hiring, training and firing costs), (ii) wage/price staggering, and (iii) labour force adjustments.

Within the CRT framework, we focus on the episodes of "high unemployment" in the Nordic countries and evaluate the extent to which capital accumulation is responsible for their diverse unemployment upturns over the last decades. Specifically, we examine the rise in Danish unemployment in the aftermath of the oil price shocks and the substantial unemployment increases in the early 1990s in all three economies. To establish a link between these unemployment upturns and the evolution of capital stock, we first identify the downturns in the growth rate of capital stock using kernel density analysis, and then conduct dynamic simulations to measure the contributions of capital stock to unemployment movements. These contributions quantify the unemployment effects of capital accumulation.

In Denmark, we find that capital stock explains around $30 \%$ of the increase in

\footnotetext{
${ }^{4}$ Kiander and Pehkonen (1999) point to the rise in interest rates (caused by the high European interest rates, the speculative attacks against the fixed exchange rate of the Finnish Markka and faster than expected disinflation) as the main factor behind the Finnish unemployment increase in the early 1990s. For Sweden, Holmlund (2006) argues that the relationship between real interest rates and unemployment is difficult to assess quantitatively and the empirical evidence not conclusive.

${ }^{5}$ See, for example, Karanassou and Snower (1998), and Karanassou, Sala and Snower (2006a).

${ }^{6}$ The interplay between lagged adjustment processes and growing exogenous variables gives rise to the phenomenon of frictional growth. For a detailed analysis of the implications of frictional growth see Karanassou, Sala, and Salvador (2006), and Karanassou and Snower (2007).
} 
unemployment in the aftermath of the oil price shocks and near $15 \%$ of the increase in the crisis of the early 1990s. In Sweden, capital accumulation contributes to $50 \%$ of the unemployment upsurge during the 1990s. Finally, the unemployment rate in Finland would have been 5 percentage points lower in the absence of the 1992 permanent drop in its capital stock growth rate.

The rest of the paper is structured as follows. Section 2 outlines the macro labour literature on the effects of capital on unemployment. Section 3 uses an analytic labour market model to highlight the capital stock-unemployment relationship according to the chain reaction theory. Section 4 presents the estimated equations for the Nordic economies. Section 5 associates the episodes of high unemployment in these countries with the slowdown in the growth rate of their capital stocks. Section 6 concludes.

\section{An Overview of the Capital-Unemployment Re- lationship}

The role of capital accumulation in the evolution of the unemployment rate has gradually regained the interest of macro-labour economists and the resulting literature is extensive and fast growing. We present a selection of papers in chronological order, and then briefly discuss the labour market doctrine that capital accumulation does not affect unemployment in the long-run.

Bean and Dréze (1991) focus on the sluggish wage response to the productivity growth slowdown in Europe in the aftermath of the oil price shocks and show that wage stickiness reduced employment and, hence, the capital stock profit rate. In turn, this prompted a decline in investment and capital accumulation that further increased unemployment.

Phelps (1994, ch. 17) empirically asserts that the unemployment rate is influenced by trendless transformations of the capital stock such as the ratio of capital to labour (in efficiency units).

Gordon (1997) argues that the unemployment-productivity tradeoff (UPT) schedule shifts with movements in capital relative to a fixed level of employment, and finds that "countries with the largest increases in unemployment had the largest slowdowns in the growth rate of capital per potential labour hour," p. 459. However, the UPT schedule is flat in the long-run, implying no relationship between changes in productivity and changes in unemployment beyond the medium-term.

Rowthorn (1999) shows that the capital labour ratio affects unemployment in the long-run when the elasticity of substitution between capital and labour is less than unity - he finds that this elasticity is, typically, between 0.6 and 0.8 . 
Modigliani (2000) shows that there is a strong negative correlation between the investment and unemployment rates - this was dubbed the "Modigliani puzzle" by Blanchard (2000, p. 140).

Arestis and Biefang-Frisancho Mariscal (2000) claim that capital formation is an important variable in the determination of unemployment and wages. Their model shows that the NAIRU is a declining function of capital stock and they find significant effects of capital accumulation on unemployment in the UK and Germany.

Malley and Moutos (2001) show that the unemployment rate is affected in the longrun when domestic and foreign capital stocks grow at unequal rates.

Karanassou Sala and Snower $(2003,2004)$ find that the decline in capital formation is crucial for understanding the EU unemployment experience in the 1970s and 1980s.

Stockhammer (2004) finds that capital accumulation is significantly related to the unemployment rate in the core European economies and the US. In contrast, he finds no robust support for the influence of wage-push factors on unemployment.

Karanassou and Snower (2004) show that the long-run unemployment rate depends on the size of capital stock and that restrictions on the relationships between the longrun growth rates (as opposed to the levels) of capital stock and other growing exogenous variables are sufficient for ensuring that the unemployment rate is trendless in the longrun.

Kapadia (2005) provides an analytic model the link between capital stock and equilibrium unemployment.

Blanchard (2005) claims that capital accumulation has influenced the evolution of European unemployment rate over three decades.

Smith and Zoega (2005) find that investment (as a ratio of GDP) has been the driving force of unemployment in the OECD countries since the 1960s.

Arestis, Baddeley and Sawyer (2007) find a robust negative relationship between capital accumulation and unemployment in nine EMU countries.

Bande and Karanassou (2007) document the importance of capital stock in explaining the Spanish regional labour market performance.

At the other end of the spectrum lies an influential strand of the literature (see the prominent work of Layard, Nickel, and Jackman, 1991, hereafter LNJ) arguing that upward shifts in the time path of capital stock lead to countervailing shifts in the wage-setting curve so as to restore unemployment to its original long-run equilibrium.

In fact, this hypothesis is the outcome of a specific wage bargaining process characterised by the following two conditions: ${ }^{7}$ (i) enhanced efficiency - resulting from higher levels of productivity, quicker capital accumulation or technological change - is translated into a wage rise by the workers (or their representatives, the unions), and (ii) the

\footnotetext{
${ }^{7}$ Wage bargaining processes are modelled via insider-outsider, union or efficiency wage models.
} 
reservation wage is a constant proportion of income and changes in line with wages. ${ }^{8}$ These conditions imply that efficiency gains are absorbed by wage rises and not translated into employment gains.

The above framework is summarised by the wage setting equation in Blanchard and Katz (1999, p.69):

$$
\left(w_{t}-p_{t}^{e}\right)=\mu b_{t}+(1-\mu) y_{t}-\beta u_{t}+\varepsilon_{t},
$$

where $w$ is the wage, $p^{e}$ expected prices, $b$ unemployment benefits (proxy of the reservation wage), $y$ labour productivity, and $\mu$ is a parameter such that $0<\mu<1$. Observe that any increase in $y$ rises real wages by some proportion $(1-\mu)$. This could still generate some employment gains, but these are absorbed by the unemployment benefits. Combined with the assumption of a unit elasticity of substitution between capital and labour - typically by assuming a Cobb-Douglas production function - this framework guarantees that any wage rise due to efficiency gains is translated into higher capital stock leaving (un)employment unchanged.

The LNJ model forms the basis of the economic policies that claim to reduce unemployment by suppressing wage-push factors such as unemployment benefits, firing restrictions, minimum wages, union power or taxes. On one hand, workers' bargaining power absorbs productivity gains, and on the other, unemployment benefits lower the possibility that efficiency gains translate into employment ones. Since the LNJ framework of analysis does not accommodate any influence of capital accumulation on the unemployment rate, it isolates the labour market from the business cycle and economic growth branches of macroeconomics.

In contrast, the labour market framework presented below draws from the chain reaction theory and allows the movements in capital stock to feed through to the unemployment rate.

\section{Capital Stock and the Chain Reaction Theory}

The Chain Reaction Theory (CRT) postulates that the evolution of unemployment can be explained by an interactive dynamics labour market model, i.e. a system of dynamic equations with spillover effects. Unlike single-unemployment rate models, the CRT models can also include trended exogenous variables - the only requirement is that each growing endogenous variable (e.g. employment, real wage, labour force) is balanced with the set of its explanatory variables.

The analytical model below offers an exposition of the CRT and is in line with the

\footnotetext{
${ }^{8}$ It is important to note that unemployment benefits are commonly used as a measure of the reservation wage. Assuming that the latter is a constant proportion of income implies a constant replacement rate.
} 
estimated labour market model presented in the next Section. In particular, we consider the following labour demand, real wage, and labour supply equations: ${ }^{9}$

$$
\begin{aligned}
n_{t} & =\alpha_{1} n_{t-1}+\beta_{1} k_{t}-\gamma_{1} w_{t}, \\
w_{t} & =\alpha_{2} w_{t-1}+\beta_{2} x_{t}-\gamma_{2} u_{t}, \\
l_{t} & =\beta_{3} z_{t}+\gamma_{3} w_{t},
\end{aligned}
$$

where $n_{t}, w_{t}$, and $l_{t}$ denote employment, real wage, and labour force, respectively; $k_{t}$ is real capital stock, $x_{t}$ represents a wage-push factor, and $z_{t}$ is working-age population; the $\beta$ 's, and $\gamma$ 's are positive constants. The autoregressive parameters $\alpha_{1}$ and $\alpha_{2}$ are positive and less than unity, and can be justified as employment adjustment and wage/price staggering effects, respectively. All variables are in logs and we ignore the error terms for ease of exposition. The unemployment rate (not in logs) is ${ }^{10}$

$$
u_{t}=l_{t}-n_{t}
$$

We generally refer to lags of the endogenous variables in the labour market model as the "lagged adjustment processes". Observe that the $\gamma$ 's generate spillover effects, since changes in an exogenous variable, say capital stock, can also affect the real wage and labour supply equations. Thus, in the presence of spillover effects, the short-run elasticities of the dependent variables with respect to the exogenous ones can no longer be adequately captured by the $\beta$ 's. It is worth pointing out that the existence of spillover effects in a multi-equation model allows us to call it "interactive".

Let us rewrite the demand, wage, and supply equations (2)-(4) as

$$
\begin{aligned}
\left(1-\alpha_{1} B\right)\left(1-\alpha_{2} B\right) n_{t} & =\beta_{1}\left(1-\alpha_{2} B\right) k_{t}-\gamma_{1}\left(1-\alpha_{2} B\right) w_{t} \\
\left(1-\alpha_{2} B\right) w_{t} & =\beta_{2} x_{t}-\gamma_{2} u_{t} \\
\left(1-\alpha_{1} B\right)\left(1-\alpha_{2} B\right) l_{t} & =\beta_{3}\left(1-\alpha_{1} B\right)\left(1-\alpha_{2} B\right) z_{t}+\gamma_{3}\left(1-\alpha_{1} B\right)\left(1-\alpha_{2} B\right) w_{t}
\end{aligned}
$$

where $B$ is the backshift operator, and substitute (7) into (6) and (8) to obtain the

\footnotetext{
${ }^{9}$ It can be shown that the labour market model (2)-(4) is compatible with standard microeconomic foundations. See, for example, Karanassou, Sala, and Snower (2006b).

${ }^{10}$ Since labour force and employment are in logs, the unemployment rate can be approximated by their difference.
} 
following equations for employment and labour force:

$$
\begin{aligned}
\left(1-\alpha_{1} B\right)\left(1-\alpha_{2} B\right) n_{t}= & \beta_{1}\left(1-\alpha_{2} B\right) k_{t}-\gamma_{1} \beta_{2} x_{t}+\gamma_{1} \gamma_{2} u_{t}, \\
\left(1-\alpha_{1} B\right)\left(1-\alpha_{2} B\right) l_{t}= & \beta_{3}\left(1-\alpha_{1} B\right)\left(1-\alpha_{2} B\right) z_{t}+ \\
& \gamma_{3} \beta_{2}\left(1-\alpha_{1} B\right) x_{t}-\gamma_{3} \gamma_{2}\left(1-\alpha_{1} B\right) u_{t}
\end{aligned}
$$

respectively.

Finally, we derive the reduced form dynamics of the unemployment rate by inserting the above equations into $(5):{ }^{11}$

$$
\begin{aligned}
{\left[\left(1-\alpha_{1} B\right)\left(1-\alpha_{2} B\right)+\gamma_{3} \gamma_{2}\left(1-\alpha_{1} B\right)+\gamma_{1} \gamma_{2}\right] u_{t}=} & -\beta_{1}\left(1-\alpha_{2} B\right) k_{t} \\
& +\gamma_{3} \beta_{2}\left(1-\alpha_{1} B\right) x_{t}+\gamma_{1} \beta_{2} x_{t} \\
& \beta_{3}\left(1-\alpha_{1} B\right)\left(1-\alpha_{2} B\right) z_{t} .
\end{aligned}
$$

The above equation is also called the univariate representation of unemployment, since no other endogenous variables feature in the equation. The term "reduced form" relates to the fact that the parameters of the equation are not estimated directly, instead, they are some nonlinear function of the parameters of the underlying labour market system (2)-(4).

In the light of equation (11), we can make the following observations. If $\gamma_{2}=0$, changes in capital stock $\left(k_{t}\right)$ and working-age population $\left(z_{t}\right)$ do not spillover in the labour market system. ${ }^{12}$ Therefore, the effects of these variables on unemployment can be adequately captured by the labour demand (2) and supply (4) equations, respectively. If, on the other hand, $\gamma_{2} \neq 0$ but either $\gamma_{1}=0$ or $\gamma_{3}=0$, any change in the exogenous variables will still generate spillover effects - the reduced form unemployment rate equation (11) takes these effects into account. However, when $\gamma_{2} \neq 0$ and $\gamma_{1}=\gamma_{3}=0$, there are no spillover effects in the system. In this case, $x_{t}$ cannot influence unemployment and the unemployment equation (11) becomes redundant.

We can reparameterise the univariate representation of the unemployment rate (11) as

$$
\begin{aligned}
u_{t}= & \phi_{1} u_{t-1}-\phi_{2} u_{t-2}-\theta_{k} k_{t}+\theta_{x}\left(\gamma_{1}+\gamma_{2}\right) x_{t}+\theta_{z} z_{t}+ \\
& \alpha_{2} \theta_{k} k_{t-1}-\alpha_{1} \gamma_{3} \theta_{x} x_{t-1}-\left(\alpha_{1}+\alpha_{2}\right) \theta_{z} z_{t-1}+\alpha_{1} \alpha_{2} \theta_{z} z_{t-2},
\end{aligned}
$$

\footnotetext{
${ }^{11}$ Note that (11) is dynamically stable since (i) products of polynomials in $B$ which satisfy the stability conditions are stable, and (ii) linear combinations of dynamically stable polynomials in $B$ are also stable.

${ }^{12}$ This is because labour demand and labour supply are linked via wages. If changes in the capital stock and working-age population do not influence wages $\left(\gamma_{2}=0\right)$ they cannot spillover to the system. The individual labour demand and supply equations can sufficiently capture their effects on unemployment.
} 
where $\phi_{1}=\frac{\alpha_{1}+\alpha_{2}+\alpha_{1} \gamma_{2} \gamma_{3}}{1+\gamma_{1} \gamma_{2}+\gamma_{2} \gamma_{3}}, \phi_{2}=\frac{\alpha_{1} \alpha_{2}}{1+\gamma_{1} \gamma_{2}+\gamma_{2} \gamma_{3}}, \theta_{k}=\frac{\beta_{1}}{1+\gamma_{1} \gamma_{2}+\gamma_{2} \gamma_{3}}, \theta_{x}=\frac{\beta_{2}}{1+\gamma_{1} \gamma_{2}+\gamma_{2} \gamma_{3}}$, and $\theta_{z}=\frac{\beta_{3}}{1+\gamma_{1} \gamma_{2}+\gamma_{2} \gamma_{3}}$.

The reduced form unemployment rate equation (12) displays the following key elements of the CRT. First, the autoregressive coefficients $\phi_{1}$ and $\phi_{2}$ represent the interactions of the employment adjustment $\left(\alpha_{1}\right)$ and wage-price staggering $\left(\alpha_{2}\right)$ processes. Second, the short-run coefficients of the exogenous variables embody the feedback mechanisms built in the system, since they are a function of the short-run elasticities/slopes of the individual equations (2)-(4), i.e. the $\beta$ 's, and the spillover effects ( $\gamma$ 's). Third, the interplay of the employment adjustment and wage-price staggering effects, on the one hand, and the spillover effects, on the other, gives rise to the lags of the exogenous variables. In time-series jargon, these lags are moving-average terms in (12).

Finally, the capital stock, a trended variable, features as a driving force of the unemployment rate, a stationary variable. This is a controversial and hotly debated result that we can justify as follows. Capital stock initially enters the system as a determinant of employment, a trended variable. Labour demand (2) is a balanced equation since it is dynamically stable $\left(\left|\alpha_{1}\right|<1\right)$. Similarly, the trended labour force is driven by working-age population (also a trended variable), and the static labour supply (4) is itself a balanced equation. According to (9)-(10), the labour demand and supply equations remain balanced once the wage (3) has been substituted into them. ${ }^{13}$

Therefore, the "reduced" unemployment rate equation is itself balanced, since (by (5)) it is given by the difference of the dynamically stable labour supply and demand equations. As mentioned in Section 2, Karanassou and Snower (2004) show that equilibrating mechanisms in the labour market and other markets jointly act to ensure that the unemployment rate is trendless in the long-run. These mechanisms can be expressed in the form of restrictions on the relationships between the long-run growth rates of capital stock and other growing exogenous variables. ${ }^{14}$

\footnotetext{
${ }^{13}$ Note that (9) and (10) are dynamically stable since the products of polynomials in $B$ which satisfy the stability conditions are also stable.

${ }^{14}$ Given the labour market model (2)-(5), it can be shown that the unemployment rate stabilises in the long-run if

$$
\begin{aligned}
\beta_{1}\left(1-\alpha_{2}\right) g_{k}= & \beta_{3}\left(1-\alpha_{1}\right)\left(1-\alpha_{2}\right) g_{z}+ \\
& {\left[\beta_{2} \gamma_{1}+\beta_{2} \gamma_{3}\left(1-\alpha_{1}\right)\right] g_{x}, }
\end{aligned}
$$

where $g_{k}, g_{z}$, and $g_{x}$ denote the long-run growth rates of capital stock, working-age population, and the wage-push factor, respectively. If $x_{t}$ does not grow in the long-run, the restriction simplifies to

$$
\left(\frac{\beta_{1}}{1-\alpha_{1}}\right) g_{k}=\beta_{3} g_{z} .
$$
}




\section{Econometric Analysis}

The empirical models presented below are in line with the consensus view of the labour market, according to which (i) labour demand is negative along the real wage and shifts with changes in capital stock, (ii) rises in capital deepening (a proxy for productivity) increase real wages, and (iii) labour supply is positive along the real wage. Furthermore, the common structure shared by the estimated equations facilitates comparisons among the three countries.

\subsection{Data and Methodology}

The dataset is obtained from the OECD Economic Outlook and the sample period of our analysis is 1973-2005 for Denmark, 1976-2005 for Finland, and 1966-2005 for Sweden. Table 1 gives the definitions of the variables included in the selected equations. ${ }^{15}$

\begin{tabular}{|ll|ll|}
\hline \multicolumn{3}{|l|}{ Table 1: Definitions of variables. } \\
\hline$n$ & employment $(\log )$ & $r$ & real long-term interest rate \\
$l$ & labour supply $(\log )$ & $f d$ & exports-imports (\% of GDP) \\
$w$ & real compensation per employee $(\log )$ & $\tau^{d}$ & direct tax rates (\% of GDP) \\
$u$ & unemployment rate $(l-n)$ & $\tau^{i}$ & indirect tax rates (\% of GDP) \\
$k$ & real capital stock $(\log )$ & $g$ & public expenditures (\% of GDP) \\
$k^{n}$ & capital stock per employee $(k-n)$ & $\tau^{w}$ & fiscal wedge ${ }^{16}$ \\
$z$ & participation rate $\left(\frac{\text { labour force }}{\text { working-age population }}\right)$ & $o$ & real oil prices (log) \\
\hline Source: OECD, Economic Outlook.
\end{tabular}

The estimation strategy involves the Autoregressive Distributed Lagged (ARDL) approach developed by Pesaran (1997), Pesaran and Shin (1999) and Pesaran, Shin and Smith (2001). The justification of this choice can be summarised as follows. It has been shown that the ARDL yields consistent estimates both in the short- and longrun, and can be reliably used in small samples for hypothesis testing irrespective of whether the regressors are I(1) or I(0). Therefore, the ARDL offers an alternative to the popular cointegration/error-correction methodology that avoids the pretesting problem implicit in the standard cointegration techniques - the Johansen maximum likelihood, and the Phillips-Hansen semi-parametric, fully-modified OLS procedures. Furthermore, Pesaran and Shin (1999) argue that the Phillips-Hansen and ARDL approaches are directly comparable, and the estimator of the former is outperformed by the ARDL estimator, especially when the sample size is relatively small (as in our case).

\footnotetext{
${ }^{15}$ Note that we have experimented with a wider set of exogenous variables - social security benefits and contributions, measures of competitiveness, financial wealth, real money balances, and consumption - but these were found to have no explanatory power on the endogenous variables.

${ }^{16}$ The fiscal wedge is the sum of direct, indirect and payroll taxes as a ratio of total compensation of employees.
} 
Our dynamic labour market model comprises labour demand, wage setting, and labour supply equations: ${ }^{17}$

$$
\mathbf{A}_{0} \mathbf{y}_{t}=\sum_{i=1}^{2} \mathbf{A}_{i} \mathbf{y}_{t-i}+\sum_{i=0}^{2} \mathbf{D}_{i} \mathbf{x}_{t-i}+\varepsilon_{t}
$$

where $\mathbf{y}_{t}$ is a $(3 \times 1)$ vector of endogenous variables (employment, real wage, and labour force) $\mathbf{x}_{t}$ is a $(9 \times 1)$ vector of exogenous variables, the $\mathbf{A}_{i}$ 's and $\mathbf{D}_{i}$ 's are $(3 \times 3)$ and $(9 \times 9)$, respectively, coefficient matrices, and $\varepsilon_{t}$ is a $(3 \times 1)$ vector of strict white noise error terms.

Each equation of the labour market system (13) is estimated following the ARDL approach and the selected specifications pass a battery of diagnostic tests for serial correlation, linearity, normality, heteroskedasticity and autoregressive conditional heteroskedasticity, and structural stability. Finally, to account for potential endogeneity and cross equation correlation we estimate the labour market model for each country with 3SLS. These estimated equations, together with the definition (5), are then used to obtain the "reduced form" unemployment rate equation underlying the rest of our empirical analysis.

In what follows we discuss our estimation results and provide an overall evaluation of the selected labour market models. ${ }^{18}$

\subsection{Labour demand}

Table 2 reports the 3SLS estimates of the employment equation for the three countries.

It is worth observing the different employment persistence across countries. Labour demand in Denmark displays the lowest persistence coefficient, 0.18, indicating a quick speed of adjustment to economic disturbances. This may reflect the high degree of flexibility which characterises the Danish labour market (the employment protection legislation is among the less strict in the OECD countries). In turn, the persistence coefficients in Sweden and Finland are substantially higher and amount to 0.66 and 0.64, respectively. Note that in Sweden the multiplicative dummies, $n_{t-1}^{d 1}$ and $n_{t-1}^{d 2}$, take into account the significant decrease in employment persistence over 1991-2005. ${ }^{19}$

\footnotetext{
${ }^{17}$ The dynamic system (13) is stable if, for given values of the exogenous variables, all the roots of the determinantal equation

$$
\left|\mathbf{A}_{0}-\mathbf{A}_{1} B-\mathbf{A}_{2} B^{2}\right|=0
$$

lie outside the unit circle. Note that the estimated equations given below satisfy this condition.

${ }^{18}$ Although Tables 2-4 below only give the 3SLS results, the OLS estimates together with the results on the misspecification tests are available upon request.

${ }^{19}$ We believe the decrease in persistence over that period is related to the boost in the active labour market programmes (ALMPs) - with increases in the volume of training programmes and expansion of subsidised employment and youth practice programmes - and the extension of the maximum permitted duration for probationary contracts from 6 to 12 months. Note that $n_{t-1}^{d i}=d i \times n_{t-1}$, for $i=1,2$,
} 


\begin{tabular}{|c|c|c|c|c|c|c|c|c|}
\hline \multicolumn{3}{|c|}{ Denmark (1973-2005) } & \multicolumn{3}{|c|}{ Sweden (1966-2005) } & \multicolumn{3}{|c|}{ Finland (1976-2005) } \\
\hline const. & 11.6 & [0.000] & const. & 2.88 & {$[0.046]$} & const. & 2.95 & {$[0.004]$} \\
\hline$n_{t-1}$ & 0.18 & {$[0.144]$} & $n_{t-1}$ & 0.66 & {$[0.000]$} & $n_{t-1}$ & 0.64 & {$[0.000]$} \\
\hline$\Delta n_{t-1}$ & 0.61 & {$[0.000]$} & $n_{t-1}^{d 1}$ & -0.001 & {$[0.140]$} & $\Delta n_{t-1}$ & 0.19 & {$[0.046]$} \\
\hline$w_{t}$ & -0.58 & {$[0.009]$} & $n_{t-1}^{d 2}$ & -0.003 & {$[0.005]$} & $w_{t}$ & 0.71 & {$[0.000]$} \\
\hline$w_{t-1}$ & -0.30 & {$[0.052]$} & $w_{t}$ & -0.78 & {$[0.000]$} & $w_{t-1}$ & -0.95 & {$[0.000]$} \\
\hline$k_{t}$ & 0.48 & {$[0.000]$} & $w_{t-1}$ & 0.67 & {$[0.000]$} & $k_{t}$ & 0.28 & {$[0.001]$} \\
\hline$\Delta k_{t}$ & 1.78 & {$[0.000]$} & $k_{t}$ & 0.22 & {$[0.002]$} & $\Delta k_{t}$ & 1.87 & {$[0.001]$} \\
\hline$\Delta k_{t-1}$ & 1.14 & {$[0.082]$} & $\Delta k_{t}$ & 2.56 & {$[0.000]$} & $r_{t}$ & -0.34 & {$[0.009]$} \\
\hline$g_{t}$ & 1.02 & {$[0.001]$} & $\tau_{t}^{i}$ & -1.08 & {$[0.004]$} & $f d_{t}$ & 0.34 & {$[0.007]$} \\
\hline$\Delta g_{t}$ & -0.89 & {$[0.011]$} & & & & & & \\
\hline$\Delta g_{t-1}$ & 0.95 & {$[0.003]$} & & & & & & \\
\hline$R^{2}$ & \multicolumn{2}{|c|}{0.981} & \multicolumn{3}{|c|}{0.935} & & \multicolumn{2}{|c|}{0.971} \\
\hline
\end{tabular}

The effect of capital stock is significant in all three economies, with a long-run elasticity of 0.6 in Denmark (i.e. a $1 \%$ rise in $k$ boosts employment by $0.6 \%$ ), 0.7 in Sweden, and 0.8 in Finland. Note that all these values are in the range given by Rowthorn (1999).

Furthermore, employment in Denmark is very sensitive to wage variations; the longrun elasticity of almost negative unity comes as no surprise in such a flexible labour market. The long-run wage elasticities in Sweden and Finland are -0.3 and -0.7, respectively. The latter is in line with Kiander and Pehkonen (1999) who show that wages affect the Finnish labour demand with an elasticity between -0.3 and -0.8 , depending on the sample period.

Further to the above common determinants, we have also identified idiosyncratic influences. Government expenditures in Denmark, indirect taxes in Sweden, and real interest rates and foreign demand in Finland.

The strong influence of government expenditures on the Danish economy relates to the fact that its public sector is responsible for the production of the vast majority of services and accounts for almost a third of total employment. ${ }^{20}$ The role of interest rates in the Finnish unemployment rate has been extensively studied by Kiander and Pehkonen (1999), Honkapohja and Koskela (1999) and Fregert and Pehkonen (2006). In turn, the presence of foreign demand captures the important export-led recovery of the Finnish economy during the last decades, a phenomenon that Kiander and Pehkonen (1999) found significant in explaining the unemployment trajectory.

where the dummy $d 1$ takes the value 1 over the period 1991-1994, zero otherwise, and the dummy $d 2$ takes the value 1 over the period 1995-2005, zero otherwise.

${ }^{20}$ See Karanassou, Sala and Salvador (2006) for a detailed analysis of the Danish labour market. 


\subsection{Wage setting}

Table 3 below presents the 3SLS estimates of the real wage equation for the three countries.

Similarly to the labour demand, wage setting exhibits different degrees of persistence across countries. As expected, the quickest adjustment takes place in Denmark, where the inertia coefficient is 0.32 , with Sweden, 0.62, and Finland, 0.80, displaying more sluggishness.

\begin{tabular}{|c|c|c|c|c|c|c|c|c|}
\hline \multicolumn{3}{|c|}{ Denmark (1973-2005) } & \multicolumn{3}{|c|}{ Sweden (1966-2005) } & \multicolumn{3}{|c|}{ Finland (1976-2005) } \\
\hline const. & 5.34 & {$[0.000]$} & const. & 3.24 & {$[0.000]$} & const. & 1.52 & [0.037] \\
\hline$w_{t-1}$ & 0.32 & {$[0.003]$} & $w_{t-1}$ & 0.62 & {$[0.000]$} & $w_{t-1}$ & 0.80 & {$[0.000]$} \\
\hline$\Delta w_{t-1}$ & 0.44 & {$[0.000]$} & $\Delta w_{t-1}$ & 0.21 & [0.046] & & & \\
\hline$u_{t}$ & -0.60 & {$[0.000]$} & $u_{t}$ & -0.67 & {$[0.004]$} & $u_{t}$ & -0.59 & {$[0.000]$} \\
\hline$k_{t}^{n}$ & 0.31 & {$[0.000]$} & $k_{t}^{n}$ & 0.31 & {$[0.000]$} & $k_{t}^{n}$ & 0.22 & {$[0.039]$} \\
\hline \multirow[t]{3}{*}{$r_{t}$} & 0.38 & {$[0.000]$} & $\tau_{t}^{d}$ & 0.63 & {$[0.004]$} & $\tau_{t}^{w}$ & 0.27 & {$[0.008]$} \\
\hline & & & $\tau_{t-1}^{d}$ & -0.46 & {$[0.056]$} & $o_{t}$ & 0.02 & {$[0.003]$} \\
\hline & & & $\tau_{t}^{i}$ & -0.78 & {$[0.003]$} & & & \\
\hline$R^{2}$ & \multicolumn{2}{|c|}{0.995} & \multicolumn{3}{|c|}{0.995} & & \multicolumn{2}{|c|}{0.995} \\
\hline
\end{tabular}

Furthermore, wages in all three countries are influenced by unemployment and capital deepening with the expected negative and positive signs, respectively. It is important to note that capital deepening (defined as the log of capital stock per employee) is a standard proxy of (the log of) labour productivity and several studies document its significance in the Nordic economies - Hansen and Warne (2001) in Denmark, Hjelm (2006) in Sweden, and Kiander and Pehkonen (1999) in Finland. In particular, the latter find that capital deepening is the most important factor in wage setting with a long-run elasticity close to unity. In our estimations, the long-run "productivity" elasticity of wage is close to unity in Sweden and Finland (0.82 and 1.10, respectively), while in Denmark it is only 0.46 .

The absence of social security benefits and contributions from our estimations may appear striking, at first sight, given the important role usually assigned to these institutional variables. Note, however, that wage setting in Finland is influenced by the fiscal wedge, while wages in Sweden are affected by direct and indirect taxes. These results are consistent with other findings in the literature. Pehkonen (1999), and Kiander and Pehkonen (1999) outline the harmful employment effects of the steady growth in the fiscal wedge via the increasing wage pressure brought by the higher income and payroll 
taxes used to finance the Finnish pension and unemployment insurance systems. Regarding Sweden, the significance of taxes is also acknowledged by Forslund (1995), and Fregert and Pehkonen (2006), among others. We can thus argue that taxes and fiscal wedge capture the effect of wage push factors, such as benefits and contributions, in wage setting.

In Denmark, real interest rates contribute positively to real wages due to their downward pressure on prices. ${ }^{21}$ Finally, the sensitivity of wages to oil prices, in Finland, signifies the exposure of this labour market to external shocks (see also Honkapohja and Koskela, 1999).

\subsection{Labour supply}

Table 4 below gives the 3SLS estimates of the labour force equation for the three countries.

In contrast with labour demand and wage setting, labour supply in Denmark features the highest persistence among the three economies. Note also that, while in Sweden and Finland stickiness in labour supply decisions does not differ substantially from that of labour demand and wage setting, in Denmark labour market flexibility is attained via quick labour demand and wage adjustments.

\begin{tabular}{|c|c|c|c|c|c|c|c|c|}
\hline \multicolumn{3}{|c|}{ Denmark (1973-2005) } & \multicolumn{3}{|c|}{ Sweden (1966-2005) } & \multicolumn{3}{|c|}{ Finland (1976-2005) } \\
\hline const. & 1.24 & {$[0.000]$} & const. & 4.55 & {$[0.000]$} & const. & 3.76 & [0.000] \\
\hline$l_{t-1}$ & 0.90 & {$[0.000]$} & $l_{t-1}$ & 0.64 & {$[0.000]$} & $l_{t-1}$ & 0.70 & {$[0.000]$} \\
\hline \multirow[t]{2}{*}{$\Delta l_{t-1}$} & 0.76 & {$[0.000]$} & & & & $\Delta l_{t-1}$ & 1.33 & {$[0.000]$} \\
\hline & & & $\Delta l_{t-2}$ & -0.33 & {$[0.000]$} & $\Delta l_{t-2}$ & 0.03 & {$[0.053]$} \\
\hline$\Delta u_{t}$ & -0.04 & {$[0.031]$} & $u_{t}$ & -0.32 & {$[0.000]$} & $\Delta u_{t}$ & -0.08 & {$[0.000]$} \\
\hline$\Delta u_{t-1}$ & -0.04 & {$[0.035]$} & & & & $\Delta u_{t-1}$ & -0.01 & {$[0.444]$} \\
\hline$w_{t}$ & 0.02 & {$[0.004]$} & $w_{t}$ & 0.08 & {$[0.000]$} & $w_{t}$ & 0.05 & {$[0.000]$} \\
\hline$\Delta w_{t}$ & -0.03 & {$[0.035]$} & & & & $\Delta w_{t}$ & -0.03 & {$[0.027]$} \\
\hline$z_{t}$ & 0.18 & {$[0.000]$} & $z_{t}$ & 0.32 & {$[0.000]$} & $z_{t}$ & 0.42 & {$[0.000]$} \\
\hline$\Delta z_{t}$ & 1.09 & {$[0.000]$} & & & & $\Delta z_{t}$ & 0.85 & {$[0.000]$} \\
\hline$\Delta z_{t-1}$ & -1.04 & {$[0.000]$} & & & & $\Delta z_{t-1}$ & -1.86 & {$[0.000]$} \\
\hline$R^{2}$ & & 99 & & & 95 & & & 99 \\
\hline
\end{tabular}

The role of wages and unemployment in labour supply decisions of the three countries is as expected. Wages exert an overall positive influence, while unemployment has a

\footnotetext{
${ }^{21}$ Note that the effect of interest rates on unemployment is the expected negative one, since wages enter negatively in labour demand.
} 
negative effect (in Denmark and Finland via a discouraged workers effect, in Sweden through the level of unemployment).

Finally, it is through the participation rate instead of the working age population that we can capture demographic influences on the labour supply movements. We explain this finding by recognising that the participation rate reflects both cultural the society's attitude towards the labour market - and institutional features that have led the Nordic countries to have the highest (female and youth) participation rates in the OECD.

In particular, Denmark is the sole country where participation rates have stayed above $80 \%$ - the highest in the OECD countries - since the mid 1980s that the economy had recovered from the oil price crises. This is due to the system of Active Labour Market Policies characterising the Danish labour market that dates back to 1979. Its main objective is to promote labour market participation, thus avoiding labour shortages and ensuring the sustainability of public finances (see Andersen, 2006, and Plougmann and Madsen, 2005).

\subsection{Evaluation of the Models}

We further evaluate our empirical models with two auxiliary diagnostics. First, we test whether the long-run relationships implied by our estimations comprise cointegrating vectors within the Johansen framework. Once the maximal eigenvalue and trace statistics confirm that the variables involved in each equation are cointegrated, the Johansen's cointegrating vectors are restricted to take the corresponding long-run values of our estimated equations. Table 5 displays the LR tests following a $\chi^{2}(\cdot)$ distribution. ${ }^{22}$ Observe that the restrictions cannot be rejected at conventional sizes of the test, indicating that the estimation methodology we followed conforms with the Johansen procedure.

\begin{tabular}{|c|c|c|c|}
\hline & Labour demand & Wage setting & Labour force \\
\hline Denmark & $\chi^{2}(2)=8.79$ & $\chi^{2}(2)=1.87 \quad[0.393]$ & $\chi^{2}(1)=0.24 \quad[0.622]$ \\
\hline Finland & $\chi^{2}(2)=1.08$ & $\chi^{2}(2)=2.78 \quad[0.249]$ & $\chi^{2}(1)=2.90 \quad[0.089]$ \\
\hline Sweden & $\chi^{2}(2)=1.89$ & $\chi^{2}(2)=1.05 \quad[0.591]$ & $\chi^{2}(1)=2.52[0.113]$ \\
\hline
\end{tabular}

\footnotetext{
${ }^{22}$ It should be noted that we only consider the $\mathrm{I}(1)$ variables in our models: $n_{t}, w_{t}, l_{t}$, and $k_{t}$ (recall that $\left.k_{t}^{n}=k_{t}-n_{t}\right)$. Therefore, we test two restrictions in the labour demand and wage setting equations and one in the labour suply equation. To conserve space, we do not report the results of the underlying unit root tests and the details of the cointegration analysis - these are available upon request.
} 
Second, we check the model's ability to replicate the actual facts. As Figure 3 shows, the estimated labour market models track actual unemployment very closely in all three countries - the only exception is the early part of the sample for Sweden. However, we do not find this discrepancy unsettling, since it is probably due to shocks affecting the foreign sector of the Swedish economy (e.g. devaluations) that dissipated by the late 1970s. In addition, the 1990s slump which is the central focus of our analysis is tracked very precisely.

Figure 3. Unemployment rate: actual and fitted values

a. Denmark

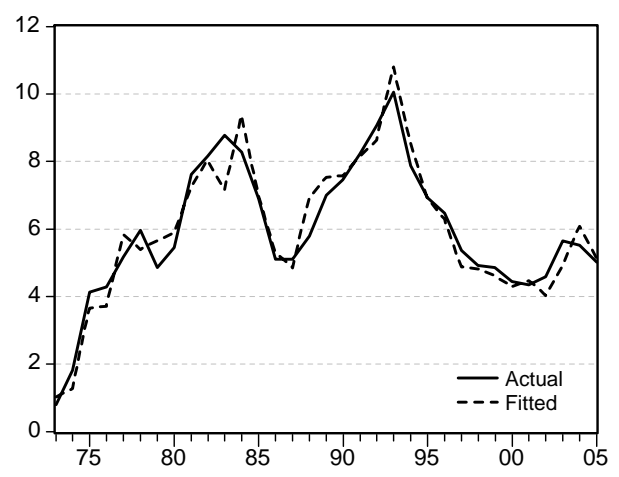

c. Finland

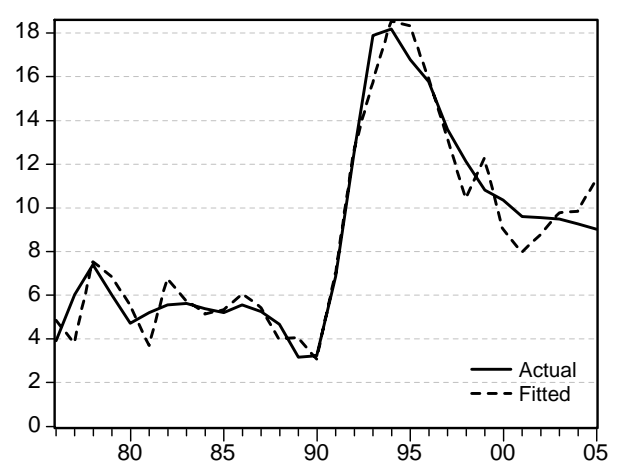

b. Sweden

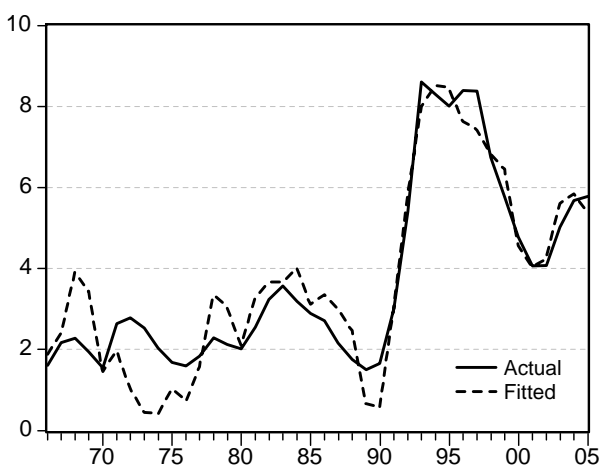

\section{Contributions of Capital Accumulation to Unem- ployment}

The Nordic countries are generally treated as a relatively homogenous area which is compared with other groups such as the Continental European or the Anglo-Saxon economies. However, the plots in Figure 3 evidence the significant disparities in the unemployment trajectories of the three countries. 
In the last decades Denmark has experienced two periods of rising unemployment, the first one in the aftermath of the oil price shocks with a rise of 8 percentage points (from $0.8 \%$ in 1973 to $8.8 \%$ in 1983), and the second one in the late 1980 s and early 1990s with the unemployment rate doubling from $5.1 \%$ in 1987 to $10.0 \%$ in 1993 .

In contrast, the Finnish and Swedish experiences are characterised by a long period of low unemployment lasting until the end of the 1980s, which was abruptly terminated in the early 1990s. For this, and other reasons, these two countries are sometimes referred to as the "twin economies," even though their unemployment trajectories display clear differences in terms of magnitudes. For example, the rate of unemployment in Sweden was on average 2.5-3 percentage points lower than that in Finland during the "full-employment" period. In the recession of the early 1990s, the Swedish unemployment rate never exceeded $8.6 \%$, while the Finnish unemployment rate was pushed to a high of $18.2 \%$. Finally, in the subsequent recovery, the difference between the two unemployment rates remained above 5 percentage points until 2003.

In what follows we argue that the evolution of capital stock accumulation can account for the disparities in the unemployment trajectories of the Nordic economies. In particular, we show that, feeding through the labour market system, the investment downturns give rise to the unemployment rate upturns and drive their intensity and longevity.

\subsection{Identification of Capital Stock Downturns}

We identify the investment downturns by estimating the kernel density function of the capital stock growth rate. ${ }^{23}$ This allows us to distinguish between the permanent and transitory components of the variable. Obviously, the term "permanent component" is not a universal concept - it only applies to our sample period. We should note that the kernel density analysis provides a simple and transparent way of determining the number and duration of investment slowdowns.

A stationary time series with different regimes is characterised by a multimodal density of its frequency distribution, the number of modes corresponding to the number of regimes. In particular, a unimodal kernel density indicates that a unique regime exists with mean equal to the value of the mode. On the other hand, a variable with two regimes displays a bimodal kernel density with a "valley point" dividing the observations in the sample. The data points are grouped in the two regimes depending on whether they lie to the left or to the right of the "valley point". The kernel density analysis of the two-regime case can easily be extended to account for three or more regimes.

\footnotetext{
${ }^{23}$ Bianchi and Zoega (1998) use kernel density functions to examine the regime-mean shifts of unemployment in 15 OECD countries. Raurich, Sala and Sorolla (2006) apply the kernel density analysis to compare the relationship of unemployment and capital accumulation in the EU and the US.
} 
Naturally, when the variable is characterised by one regime, this is taken to be permanent. For multimodal kernel densities we distinguish between permanent and temporary regimes and identify them as follows. The variable starts in one regime (say, A) in the beginning of the sample, and then moves to another regime (say, B) at some later point in time. If the variable reverses to regime A before the end of the sample, then regime $\mathrm{B}$ is temporary and regime $\mathrm{A}$ is permanent. On the other hand, if the variable stays in regime B by the end of the sample then both regimes are permanent ones.

Figure 4. Capital accumulation in the Nordic countries

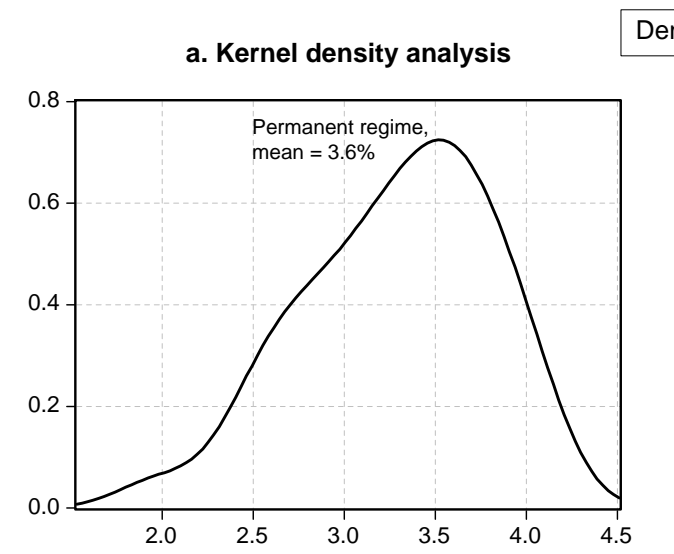

Denmark

b. Capital accumulation

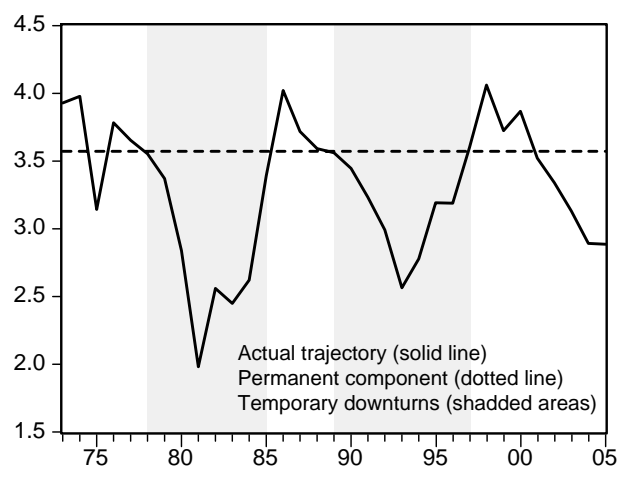

c. Kernel density analysis

Sweden

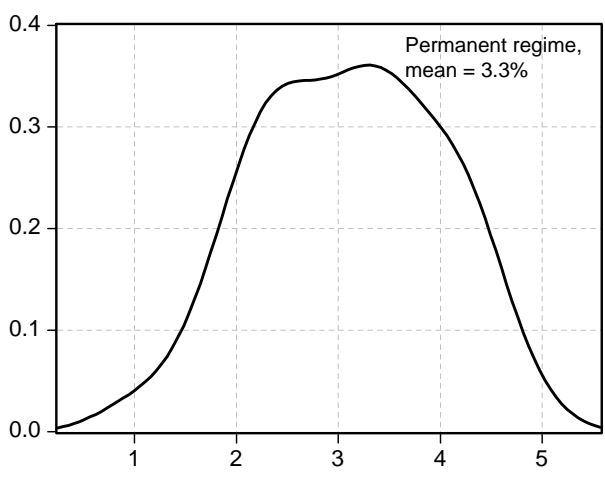

d. Capital accumulation

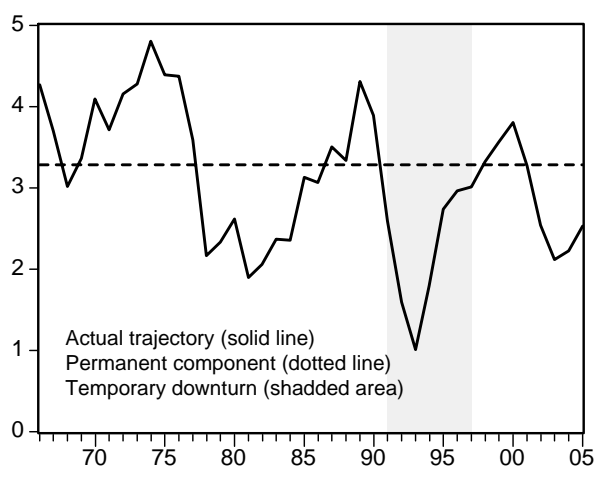

e. Kernel density analysis

Finland

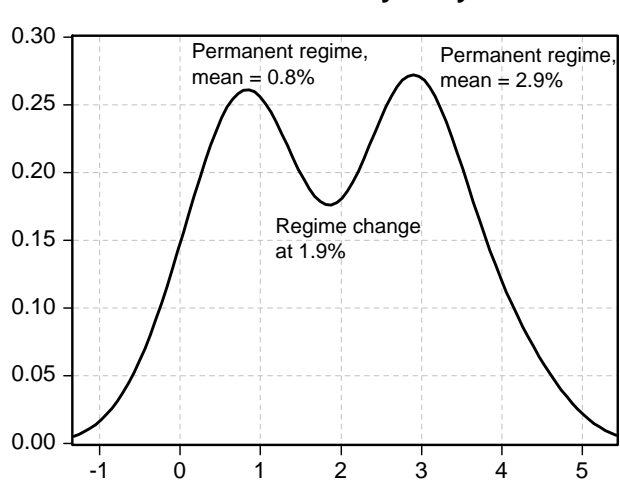

f. Capital accumulation

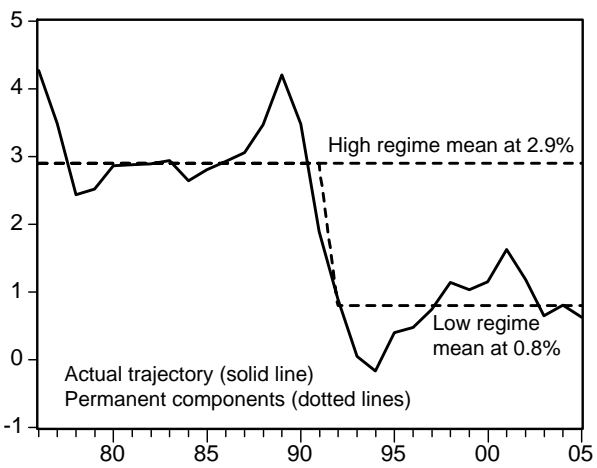


The plots of the kernel density functions in the first column of Figure 4 reveal the number of regimes for the capital stock growth rates of the Nordic economies. The plots in the second column of Figure 4 display the actual series (solid lines) and the mean values of their permanent regimes (dotted lines).

According to Figure 4a, the growth rate of capital stock in Denmark displays a single regime with mean 3.6\%. Figure $4 \mathrm{~b}$ shows that Denmark experienced two downturns in investment over the 1978-1985 and 1989-1997 periods with the growth rate of capital stock reaching a low of $2.0 \%$ in 1981 and $2.6 \%$ in 1993 .

Figure $4 \mathrm{c}$ shows that the growth rate of capital stock in Sweden is also characterised by one regime with mean $3.3 \%$. A temporary but prolonged downturn took place from 1991 to 1997 (see Figure 4d). In 1990 capital accumulation declined sharply from 3.9\% to $1.0 \%$ in 1993; it slowly recovered afterwards to reach its structural level by 1998 .

In contrast to Denmark and Sweden, capital accumulation in Finland displays two regimes (see Figure 4e-f). While the growth rate of capital stock fluctuates around $2.9 \%$ until 1991, it hovers around $0.8 \%$ after 1992. The slowdown in investment that persists after the 1992 structural break accompanies, strikingly well, the high unemployment era in Finland with rates between $9 \%$ and $18 \%$. Thus, the kernel density analysis helps us to understand the extremely high negative correlation between the unemployment and capital stock growth rates documented in Figure 2c.

To evaluate the unemployment contributions of the above identified downturns in capital accumulation we simulate the estimated labour market model with a capital stock series that we construct by using the permanent component of capital accumulation (dotted line in Figures 4b, 4d, 4f), instead of the actual series (solid line in Figures $4 \mathrm{~b}, 4 \mathrm{~d}, 4 \mathrm{f})$.

\subsection{Denmark: the 'Anglo-Saxon' Nordic Economy}

In Denmark, we measure the unemployment effects of capital accumulation as follows. First, we simulate the Danish labour market model over the period of the first slowdown in the growth rate of capital stock, 1978-1985, using a capital stock series constructed by the 1978-1985 segment of the dotted line in Figure 4b. As shown Figure 5a, the persistent shock of the second half of the 1970s and first half of the 1980s accounts for a substantial part of the increase in Danish unemployment during this period. The unemployment rate would have been, on average, 2 percentage points lower: $5.0 \%$ instead of $7.0 \%$. Therefore, almost $30 \%$ of unemployment in the $1978-1985$ period can be explained by the decline in capital formation.

Second, we run an analogous simulation for the labour market model over the 19891997 capital accumulation slowdown. Figure 5b shows that, had the growth rate of 
capital stock remained at its structural path (dotted line in Figure 4b), unemployment would have been relatively stable (around 7\%) in the early 1990s, reaching a maximum in 1993 of $7.5 \%$ instead of its actual $10 \%$ peak. In addition, the average rate of unemployment during the 1989-1997 period would have been $6.6 \%$, one percentage point lower than its actual value.

Figure 5. Unemployment effects of capital accumulation in Denmark

a. Early 1980 s downturn

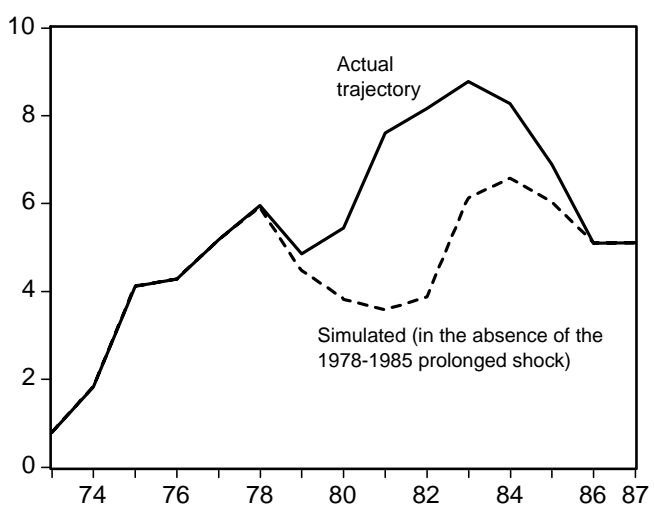

b. Early 1990s downturn

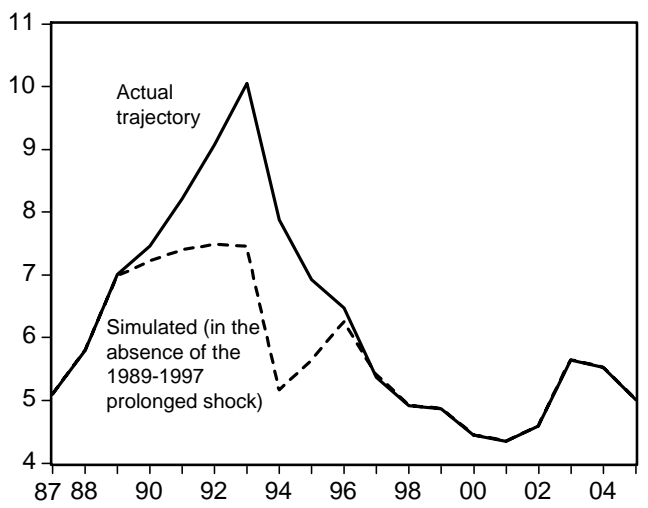

According to Honkapohja and Koskela (1999), and Koskela and Uusitalo (2006), among others, the second upturn in unemployment was prompted by the international recession and the 1989 German unification which raised interest rates all around Europe. Hence, real interest rates were a major contributor to the onset of this crisis. This meshes well with our own analysis since it is plausible to argue that the rise in interest rates is manifested in the investment slowdown after 1989 .

\subsection{The 'Twin Economies' and the 1990s Slump}

The message conveyed by the plots in Figure 1 is that the unemployment rate time paths of Sweden and Finland are rescaled versions of one another. Hence the reference to the two countries as the 'twin economies'. Below we argue that the much higher unemployment rates experienced by Finland after 1992 are due to the permanent decline in the growth rate of its capital stock occurring in 1992 (see Figures 4e-f). By contrast, in Sweden, the substantial slowdown in capital accumulation in 1991 has been reversed by 1997 (see Figures 4c-d).

In other words, the capital accumulation downturn in Sweden is transitory and we measure its effects on unemployment similarly to Denmark. We simulate the Swedish labour market model over the 1991-1997 period of the slowdown in investment, using a 
capital stock series constructed by the 1991-1997 segment of the dotted line in Figure $4 \mathrm{~d}$. Therefore, the dotted line in Figure 6 a gives the time path that the unemployment rate would have followed had capital stock continued to grow at $3.2 \%$ from 1991 to 1997. Note that while actual unemployment sharply rises to a maximum of $8.6 \%$ in 1993 and then stabilises at values above $8 \%$, the simulated series reaches its peak of $6.3 \%$ in 1998. Furthermore, the average unemployment rate would have been of $3.6 \%$ instead of $7.2 \%$, and so the capital accumulation downturn accounts for $50 \%$ of the unemployment problem over the 1991-1997 period.

Figure 6. Unemployment effects of capital accumulation in Sweden and Finland
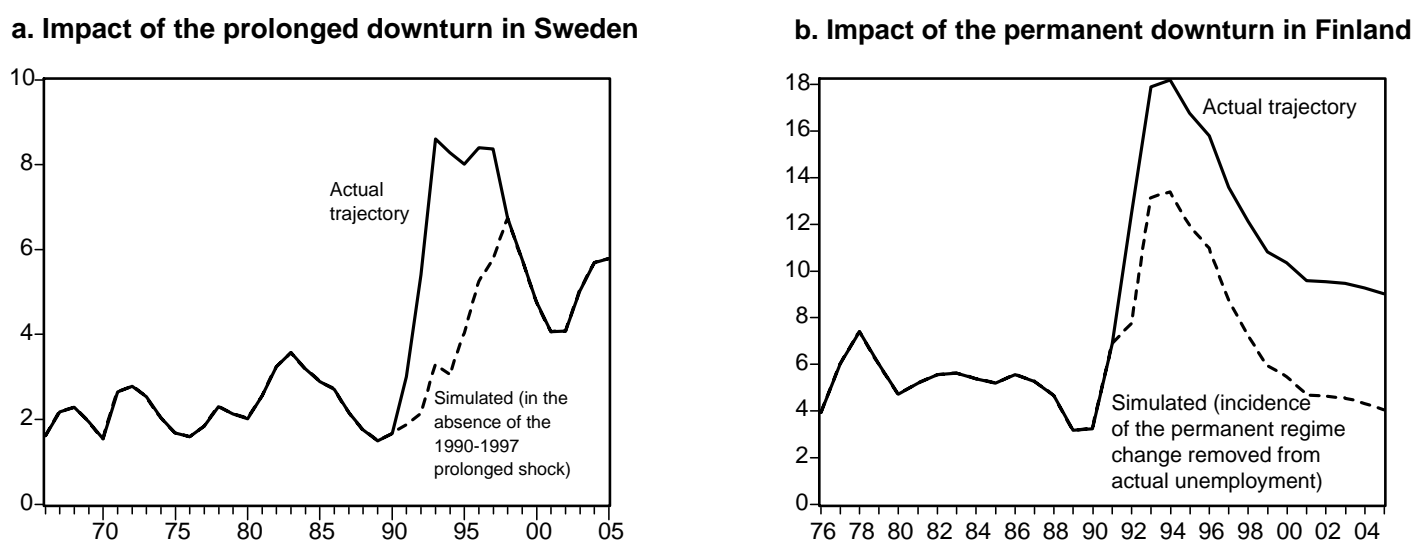

The kernel density analysis in Figures 4e-f shows that the 1992 structural break pushed the growth rate of capital stock in Finland from a high regime with mean $2.9 \%$ to a low regime with mean $0.8 \%$. We evaluate the impact of the permanent decrease in capital accumulation after 1992 as follows.

We simulate the steady state of the Finnish labour market model under two scenarios 1992 onwards: (i) a capital stock growing at $2.9 \%$, and (ii) a capital stock growing at $0.8 \%$. The reason for simulating the steady-state of the model is that we want to measure the effect of the permanent shift in the growth rate of the capital stock net of the lagged adjustments present in the labour market. The difference between the two simulated time paths of the unemployment rate is around 5 percentage points and is our measure of the unemployment contribution of the permanent decline in capital accumulation after 1992. We subtract this contribution from the actual unemployment rate and plot the resulting series in Figure $6 \mathrm{~b}$ (dotted line).

Figure $6 \mathrm{~b}$ shows that had capital growth remained at its high regime mean, unemployment would have peaked at $13.4 \%$ in 1994 instead of the actual $18.2 \%$. In turn, the actual subsequent fall to around $9 \%$ in 2005 would have ended up near $4.0 \%$. This result 
has two important implications. First, the magnitudes of the Finnish unemployment trajectory would have been much closer to the Swedish ones. We have thus identified a crucial factor explaining the disparity in the intensity of the early 1990s crisis in the so-called twin economies. Second, in the absence of the permanent slowdown in investment after 1992, Finland would have recovered the full-employment levels that had historically characterised its labour market.

Our analysis is consistent with the view of Honkapohja and Koskela (1999) that external shocks (the collapse of trade with the Soviet Union, the western recession and the rise in German interest rates) are not the main driving forces of the unemployment rate in Finland.

\section{Conclusions}

In this paper we showed that capital accumulation plays a significant role in explaining the diverse unemployment experiences of the Nordic countries.

Following the chain reaction theory (CRT) of unemployment, we estimated a dynamic labour market model with spillover effects that allows the interplay of the movements in capital stock and lagged adjustment processes to feed through to the unemployment rate. Using kernel density analysis, we identified the temporary and permanent slowdowns in capital accumulation and, focusing on the relatively high unemployment periods, we performed dynamic simulations and showed that the downturns in capital accumulation drive the intensity and longevity of the upturns in unemployment.

In particular, the unemployment swings in Denmark resemble those of the US, with peaks in the early 1980s and 1990s, hence the reference to it as the 'Anglo-Saxon' Nordic economy. We found that the persistent capital stock shocks of 1978-1985 and 1989-1997 account for approximately $30 \%$ and $15 \%$ of the rise in unemployment during these periods, respectively.

Finland and Sweden are labelled the 'twin economies' due to the similarity in their unemployment trajectories: they came out of the oil price shocks with no serious damage and faced unprecedented unemployment increases in the early 1990s. Nevertheless, the gap in the unemployment rates of the two countries in the aftermath of the 1990s crisis was substantial, reaching almost 10 percentage points. In Sweden, we found that the 1991-1997 slowdown in capital accumulation contributes to $50 \%$ of the unemployment increase during this period. Finland, unlike Denmark and Sweden, is characterised by a permanent drop in capital accumulation since 1992. Had capital accumulation remained at its high-regime mean, unemployment would have been 5 percentage points lower and the unemployment gap in the twin economies would have been substantially reduced 1992 onwards. 
Our results shift the emphasis in the determinants of unemployment from wagepush factors to capital accumulation. Instead of following the conventional policy recipe attempting to reduce unemployment by suppressing wage-push factors (such as unemployment benefits, firing restrictions, minimum wages, union power, taxes), our analysis offers a way of explaining the unemployment problem by recognising the interaction of growth and dynamics in the labour market. The significant unemployment contributions of capital accumulation imply that policies related to $\mathrm{R} \& \mathrm{D}$ activities, policies promoting innovations and productivity growth, or policies directly fostering investment and capital accumulation, can enhance the performance of the labour market.

\section{References}

[1] Andersen, T. (2006): "From Excess to Shortage - Recent Developments in the Danish Labour Market," in M. Werding (ed.) Structural Unemployment in Western Europe: Reasons and Remedies, The MIT Press, Cambridge MA, pp. 75-102.

[2] Arestis, P. and I. Biefang-Frisancho Mariscal (2000): "Capital Stock, Unemployment and Wages in the UK and Germany," Scottish Journal of Political Economy, 47 (5), pp. 487-503.

[3] Arestis, P., M. Baddeley and M. Sawyer (2007): "The relationship between capital stock, unemployment and wages in nine EMU countries," Bulletin of Economic Research, forthcoming.

[4] Bande, R. and M. Karanassou (2007): "Labour Market Flexibility and Regional Unemployment Rate Dynamics: Spain 1980-1995," IZA Discussion Paper 2593, Bonn.

[5] Bean, Ch. and J. Dréze (1991): Europe's Unemployment Problem, The MIT Press, Cambridge, MA.

[6] Bianchi, M. and G. Zoega (1998): "Unemployment Persistence: Does the size of the shock matter?," Journal of Applied Econometrics, 13 (3), pp. 283-304.

[7] Blanchard, O. (2000): "The Economics of Unemployment: Shocks, Institutions and Interactions," Lionel Robins Lectures.

[8] Blanchard, O. (2005): "Monetary Policy and Unemployment," in W. Semmler (ed.) Monetary Policy and Unemployment - US, Euro-Area, and Japan, Routledge, London.

[9] Blanchard, O.J. and L.F. Katz (1999): "Wage Dynamics: Reconciling Theory and Evidence," The American Economic Review Papers and Proceedings, 89 (2), pp. 69-74.

[10] Blanchard, O.J. and J. Wolfers (2000): "The Role of Shocks and Institutions in the Rise of European Unemployment: The Aggregate Evidence," The Economic Journal, 110 (462), pp. C1-C33.

[11] Edey, M. and K. Hviding (1995): "An Assessment of Financial Reform in OECD Countries," OECD Economic Studies, 25, OECD Publishing.

[12] Fregert, K. and Pehkonen, J. (2006): "The Crises of the 1990s and the Evolution of Unemployment in Finland and Sweden," in L. Jonung and P. Vartia (eds.) Depression in the North, forthcoming. 
[13] Forslund, A. (1995): "Unemployment-Is Sweden Still Different?," Swedish Economic Policy Review, 2, 25-58.

[14] Gordon, R.J. (1997): "Is there a trade-off between unemployment and productivity growth," in D.J. Snower and G. de la Dehesa (eds), Unemployment Policy: Government Options for the Labour Market, CU Press, Cambridge.

[15] Green-Pedersen, C. (2001): "Minority Governments and Party Politics: The Political and Institutional Background to the "Danish Miracle"," Journal of Public Policy, 21 (1), pp. 63-80.

[16] Green-Pedersen, C. and A. Lindbom (2005): "Employment and Unemployment in Denmark and Sweden: Success or Failure for the Universal Welfare Model," pp. 65-85, in U. Becker and H. Schwartz (eds.) Employment 'Miracles' in Critical Comparison. The Dutch, Scandinavian, Swiss, Australian and Irish Cases versus Germany and the USA, Amsterdam: Amsterdam University Press.

[17] Hansen, H. and Warne, A. (2001): "The Cause of Danish Unemployment: Demand or Supply Shocks?," Empirical Economics, 26, pp. 461-486.

[18] Hjelm, G. (2006): "Simultaneous determination of NAIRU, output gaps and structural budget balances: Swedish evidence," in G.L. Mazzi and G. Savio (eds.) Growth and Cycle in the Eurozone, Palgrave, Mcmillan.

[19] Honkapohja, S. and E. Koskela (1999): "Finland's depression: A tale of bad luck and bad policies," Economic Policy, 14 (29), pp. 400-436.

[20] Holmlund, B. (2006): "The Rise and Fall of Swedish Unemployment," in M. Werding (ed.) Structural Unemployment in Western Europe: Reasons and Remedies, The MIT Press, Cambridge MA, pp. 103-132.

[21] Kapadia, S. (2005): "The capital stock and equilibrium unemployment: a new theoretical perspective," Discussion Paper Series 181, Department of Economics, University of Oxford.

[22] Karanassou, M. and D.J. Snower (1998): "How Labor Market Flexibility Affects Unemployment: Long-Term Implications of the Chain Reaction Theory," The Economic Journal, 108, pp. 832-849.

[23] Karanassou, M. and D.J. Snower (2004): "Unemployment Invariance," The German Economic Review, 5 (3), pp. 297-317.

[24] Karanassou, M. and D.J. Snower (2007): "Inflation Persistence and the Phillips Curve Revisited," IZA Discussion Paper 2600, Bonn.

[25] Karanassou, M., H. Sala and P.F. Salvador (2006): "The (IR)relevance of the NRU for policy making: The case of Denmark," IZA Discussion Paper 2397, Bonn.

[26] Karanassou, M., H. Sala and D.J. Snower (2003): "Unemployment in the European Union: A Dynamic Reappraisal," Economic Modelling, 20 (2), pp. 237-273.

[27] Karanassou, M., H. Sala and D.J. Snower (2004): "Unemployment in the European Union: Institutions, Prices and Growth," CESifo Working Paper Series 1247, Munich.

[28] Karanassou, M., H. Sala and D.J. Snower (2006a): "Phillips Curves and Unemployment Dynamics: A Critique and a Holistic Perspective," IZA Discussion Paper, 2265, Bonn. 
[29] Karanassou, M., H. Sala and D.J. Snower (2006b): "The macroeconomics of the labor market: Three fundamental views," IZA Discussion Paper 2480, Bonn.

[30] Kiander, J. and Pehkonen, J. (1999): "Finnish Unemployment: Observations and Conjectures," Finnish Economic Papers, 12 (2), pp. 94-108.

[31] Koskela, E. and R. Uusitalo (2006): "The Unintended Convergence: How Finnish Unemployment Reached the European Level," in M. Werding (ed.) Structural Unemployment in Western Europe: Reasons and Remedies, the MIT Press, Cambridge MA, pp. 159-185.

[32] Layard, R., S. Nickell and R. Jackman (1991), Unemployment: Macroeconomic Performance and the Labour Market, Oxford: Oxford University Press.

[33] Malley, J. and T. Moutos (2001): "Capital Accumulation and Unemployment: A Tale of Two Continents," The Scandinavian Journal of Economics, 103 (1), pp. 79-99.

[34] Modigliani, F. (2000): "Europe's economic problems," Prepared for testimony before the Monetary Committee of the European Parliament.

[35] Pehkonen, J. (1999): "Wage formation in Finland, 1960-1994," Finnish Economic Papers, 12 (2), pp. 82-93.

[36] Pesaran, M.H. (1997): "The Role of Economic Theory in Modelling the Long-run," The Economic Journal, 107 (440), pp. 178-191.

[37] Pesaran, M.H. and Y. Shin (1999): "An Autoregressive Distributed-Lag Modelling Approach to Cointegration Analysis" in Econometrics and Economic Theory in the Twentieth Century: The Ragnar Frisch Centennial Symposium, edited by Strom, S., Cambridge University Press, pp. 371-413.

[38] Pesaran, M.H., Shin, Y. and Smith, R.J. (2001) Bounds testing approaches to the analysis of level relationships, Journal of Applied Econometrics, 16, pp. 289-326.

[39] Phelps, E. S. (1994): Structural Booms: The Modern Equilibrium Theory of Unemployment, Interest and Assets, Harvard University Press, Cambridge (MA).

[40] Plougmann, P. and P.K. Madsen (2005): "Labor market policy, flexibility and employment performance: Denmark and Sweden in the 1990s" in D.R. Howell (ed.) Fighting unemployment: The limits of free market orthodoxy, Oxford University Press.

[41] Raurich, X., H. Sala and V. Sorolla (2006): "Unemployment, Growth and Fiscal Policy: New Insights on the Hysteresis Hypotheses", Macroeconomic Dynamics, 10 (3), pp. 285-316.

[42] Rowthorn, R. (1999): "Unemployment,wage bargaining and capital-labour substitution," Cambridge Journal of Economics, 23, pp. 413-425.

[43] Smith, R. and G. Zoega (2005): "Unemployment, Investment and Global Expected Returns: A Panel FAVAR Approach," Birkbeck Working Papers in Economics 63 Finance 0524, Birkbeck College, London.

[44] Stockhammer, E. (2004): "Explaining European Unemployment: Testing the NAIRU Theory and a Keynesian Approach," International Review of Applied Economics, 18 (1), pp. 3-23. 